Vol. 5 (1996): 251-260.

\title{
Plant adaptation to temperature and photoperiod
}

\author{
Olavi Junttila \\ University of Troms $\phi, N$-9037 Troms $\phi$, Norway
}

\begin{abstract}
Plants respond to environmental conditions both by adaptation and by acclimation. The ability of the plants to grow, reproduce and survive under changing climatic conditions depends on the efficiency of adaptation and acclimation. The adaptation of developmental processes in plants to temperature and photoperiod is briefly reviewed. In annual plants this adaptation is related to growth capacity and to the timing of reproduction. In perennial plants growing under northern conditions, adaptation of the annual growth cycle to the local climatic cycle is of primary importance. Examples of the role of photothermal conditions in regulation of these phenological processes are given and discussed. The genetic and physiological bases for climatic adaptation in plants are briefly examined.
\end{abstract}

Key words: development, flowering, frost resistance, growth

\section{Introduction}

Plants respond to environmental conditions by both adaptation and acclimation. Adaptation consists of heritable modifications in structures or functions that increase the probability of an organism surviving and reproducing in a particular environment. Acclimation refers to nonheritable modifications caused by exposure of an organism to a changing environment, and is based on the structural and physiological plasticity of the plants. Plasticity is a unique feature of plants that has been suggested to have significance as an integral part of the mechanisms by which plants (a) control reproductive effort and (b) capture resources from their environments (Grime et al. 1986). Some plant characteristics, such as flower structures, seed and fruit anatomy, have very low plasticity. However, many of the basic characteristics that are important for plant growth and development and for plant yield, such as numbers of meristems, numbers of various organs, rates of division and expansion, show high plasticity (see also Trewavas 1986). Processes such as the breaking of dormancy by chilling and induction of cold hardening by low temperature treatments are also expressions of the acclimation abilities of plants. Acclimation has, of course, a genetic basis and so is linked to adaptation. High plasticity and a high capacity for acclimation can be of major adaptive significance.

The present distribution of higher plants is a reflection of an evolutionary adaptation to envi- 


\section{AGRICULTURAL AND FOOD SCIENCE IN FINLAND}

\section{Junttila, O.: Plant adaptation to temperature and photoperiod}

ronmental conditions. The first photosynthetic organisms evolved about 2500 million years ago and free oxygen based respiration developed some 2000 million years ago. From this perspective, the appearance of flowering plants 130 million years ago is a rather recent event. The present vegetation of Nordic countries evolved even more recently, about $12000-15000$ years ago. In view of these developments, the domestication and cultivation of plants have a very short history. Domestication started a humanimposed adaptation, which continues at an accelerated rate in modern plant breeding with its goal to produce species and cultivars adapted to various environments, growing conditions and purposes. These time perspectives should be kept in mind in further consideration of plant adaptation to a changing environment.

Since their first appearance, flowering plants have experienced changes in the environment, long- and short-term changes in the global climate, and climatic changes due to geographic spreading (north-south, maritime-continental). The large-scale result of environmental adaptation in plants is well demonstrated by the vast differences in vegetation types as one moves from the equator to the poles, or from maritime to continental areas. Moreover, year-to-year variations in temperature conditions may be of greater magnitude than expected temperature changes. Thus, cultivated plants, especially the annual species, have been, and are, exposed to strongly changing environments. Our understanding of plant adaptation is based both on studies of natural plant populations and on plant breeding and experiments with cultivated species (e.g. Evans 1993). Experimental studies under controlled conditions, in which various components of the climate can be studied separately and in design interactions, have been a particularly valuable source of information (e.g. Roberts et al. 1993). The phytotron is an indispensable research facility for systematically analysing the effects of climatic factors on plant growth and development, and a combination of phytotron and genetic approaches provides a powerful tool for studies on plant adaptation.
As a result of evolution and adaptation, there are 250000 species of flowering plants. Intraspecies adaptation has resulted in climatic, as well as edaphic, ecotypes. Turesson (1922) defined ecotype as a genotypic response to the various environments in which the species is found. Ecotype is also used as a part of a cline. Environmental conditions may change gradually over the geographic range of a species, and cline is used to describe a gradual change in a character over this geographic range. Quantitative, physiological characters, such as responses to photoperiod, are particularly likely to show a clinal variation, but this may also apply to morphological features (Jones and Wilkins 1971).

Plant growth arises from the production of dry matter through energy metabolism and morphological development. Both of these main processes are notably affected by environmental conditions and are subjected to adaptation and acclimation. The main emphasis here is on developmental adaptations of plants; the adaptation of dry matter production is limited to some brief comments only. In annual plants this is related to the rate of development and to the timing of reproduction. In perennial plants growing under northern conditions, adaptation of phenology, growth cycle, to the annual climatic cycle is of primary importance. As will be shown here, adaptation of these developmental processes is mainly based on responses to photothermal conditions. The physiological and certain genetic aspects of adaptation are also discussed.

\section{Adaptation of dry matter production and photosynthesis}

Plant growth depends on photosynthesis and energy metabolism. As pointed out in the introduction, these basic metabolic processes have a long evolutionary history. Due to their key role in plant growth, they have attracted a large volume of research in many fields, plant breeding among them. 
Vol. 5 (1996): 251-260.

The most important climate-related photosynthetic adaptation is development and evolution of the $\mathrm{C}_{4}$ assimilation system as an adaptation to a warmer climate. In his book Evans (1993) concludes his very comprehensive discussion with the following statements: "..the predominant improvements so far have not been in the efficiency of the major metabolic and assimilatory processes, but in the patterns of partitioning and the timing of development... Convincing evidence of improvements of the major metabolic and assimilatory processes through plant breeding is lacking, whether for photosynthesis, respiration, translocation or growth rate. Regulatory processes, by contrast, have been profoundly modified".

Strictly photoperiodic stimulation of dry matter production is important in plant production at northern latitudes and has been demonstrated in many plant species, particularly in high-latitude cultivars of perennial grass species (Hay 1990, Junttila et al. 1990a). It has been suggested that this response has adaptive significance for growth under marginal temperature conditions at high latitudes (Hay and Heide 1983). Physiologically this stimulation of dry matter production is primarily related to developmental processes promoted by a long day such as leaf development and stem growth.

\section{Adaptation of developmental processes}

The life cycle of a plant includes germination, vegetative growth, flowering and seed production. In addition, to ensure survival through unfavourable seasons, plants must have a cycle of dormancy and growth. In a seasonal habitat there is a premium on doing the right thing at the right time and the most efficient mechanism for doing this is the one most likely to be selected (Jones and Wilkins 1971). Thus, phenology - the influence of environment on ontogeny - is the most important single factor influencing genotypic adaptation (Roberts et al. 1993). In temperate-zone species, environmental regulation of phenology is controlled by the photoperiod and temperature. Photoperiod, which at a given latitude remains rather constant from year to year is the most reliable time signal. Adaptation to photoperiod has thus been marked in both plants and in animals. These adaptations are significant for survival and reproduction. In most temperate-zone woody plants, photoperiod gives the signal for cessation of growth and hardening processes, and these species show a cline of photoperiodic responses over latitudes (Vaartaja 1954, Dormling et al. 1968, Heide 1974, Håbjørg 1978). In woody plants the critical photoperiod for cessation of growth is relatively little affected by temperature (Heide 1974, Junttila 1980). Temperature can nevertheless substantially modify the process of growth cessation. Analyses of the phenology of growth cessation under natural conditions reveal a photoperiod $x$ temperature interaction (Koski 1985). Lankinen (1986), among others, has demonstrated a latitudinal cline in critical photoperiod for diapause response in Drosophila strains.

In herbaceous plants photoperiodic responses are related first of all to flowering but also to overwintering. Plant species are commonly classified into categories of long day, short day and day neutral plants. Daylength responses, however, also vary within species.

Summerfield and his colleagues have carried out detailed studies on regulation of flowering in several crop species and conclude that the time when a crop flowers is determined almost exclusively by the genetically controlled responses to daylength and temperature (Summerfield et al. 1991, Roberts et al. 1993). On the basis of experiments under controlled conditions in which temperature and photoperiod could be independently manipulated, they have developed quantitative models that are reliable enough to predict when particular genotypes will flower in any environment.

Adaptation to photoperiod and temperature for flower induction has also been shown in tem- 
Junttila, O.: Plant adaptation to temperature and photoperiod

Table 1. Primary induction requirements for flowering in some temperate perennial grasses. (Modified from Heide 1994).

\begin{tabular}{lllll}
\hline & \multicolumn{2}{l}{ In short days $(<12 \mathrm{~h})$} & \multicolumn{2}{l}{ In long days $(>16 \mathrm{~h})$} \\
& \multicolumn{2}{l}{$\begin{array}{l}\text { Temperature } \\
\left({ }^{\circ} \mathrm{C}\right)\end{array}$} & $\begin{array}{l}\text { Exposure } \\
\text { (weeks) }\end{array}$ & \multicolumn{2}{l}{$\begin{array}{l}\text { Temperature } \\
\left({ }^{\circ} \mathrm{C}\right)\end{array}$} & $\begin{array}{l}\text { Exposure } \\
\text { (weeks) }\end{array}$ \\
\hline Poa pratensis & $3-18$ & $6-10$ & $3-12$ & $8-12$ \\
Alopecurus pratensis & $6-18$ & 6 & $6-15$ & $6-8$ \\
Dactylis glomerata & $9-21$ & $8-10$ & $0-3$ & $20-$ \\
Festuca pratensis & $3-15$ & $16-20$ & $3-12$ & $18-20$ \\
\hline
\end{tabular}

perate perennial grass species (Heide 1994). The majority of such species have a dual induction requirement for flowering. Primary induction, which is brought about by low temperature and/ or short photoperiod, and secondary induction at long photoperiod and moderate or high temperatures. For primary induction, low temperature and short photoperiod can substitute for each other, and this combination provides extra insurance for effective induction, even under changing temperature conditions. As shown in selected species in Table 1, temperature limits for both primary and secondary induction are relatively wide and thus the induction process is not very sensitive to minor variations or changes in temperature. Table 1 also demonstrates differences among species, but there is also some variation within species. Generally, primary induction is reached earlier by genotypes of more northern than those of southern origin, and the critical photoperiod for secondary induction varies from 9-10 h in Mediterranean ecotypes to more than $16 \mathrm{~h}$ in high latitude ecotypes (Heide 1994). Among common pasture species, timothy (Phleum pratense L.) is an obligatory long day plant without any chilling requirement. High temperatures, however, have an inhibitory effect on flowering in timothy and northern origins appear to be more sensitive to this inhibition than southern origins (Heide 1982).

Likewise in strawberry, flower induction is controlled by interaction between photoperiod and temperature, and the degree of dependence on a short photoperiod increases with rising temperature (Heide 1977). There are significant dif- ferences between cultivars. Some cultivars, e.g. Jonsok and Glima, are able to form flower buds even under continuous light at temperatures of $12^{\circ} \mathrm{C}$ or lower (Heide 1977). In plants with this type of response to photoperiod and temperature, elevated temperature conditions combined with the long days of high latitudes can reduce flowering. Similarly, in Poa nemoralis, a long day plant, the number of panicles per plant is reduced with an increase in temperature from 9 to $21^{\circ} \mathrm{C}$ (Heide 1986). In timothy, temperatures above $15^{\circ} \mathrm{C}$ reduce flowering, particularly in cultivars with a northern origin (Junttila and Schjelderup 1984).

The actual temperature during the growth season at northern latitudes is generally lower than the optimum temperatures for both introduced and native plants, provided that adequate water and nutrients are available. Temperature requirements for, and temperature effects on, the rate of development for various developmental processes can differ between species, ecotypes and cultivars. Intraspecific genetic variation in perennial grass species with respect to growth responses to temperature has been demonstrated. Mediterranean and Scandinavian origins of Dactylis glomerata L., Lolium perenne L., and Festuca arundinaceae Schreb., for example, differ in their temperature responses (Cooper 1964, Eagles 1967). Mediterranean races generally have lower temperature minima for growth than Scandinavian races, and they have less steep growth response curves to rising temperature than do northern origins (Wareing 1979). Our studies on white clover (Trifolium 
Vol. 5 (1996): 251-260.

repens L.) have shown similar responses, with genotypes of southern origin starting to grow at lower temperatures than genotypes from northern Norway (Svenning et al. unpublished).

Although examples of the specific effects of fluctuating temperatures are known (Went 1957), many plants generally respond to the daily mean temperature. Recent studies on wheat can be taken as an example. Slafer and Rawson (1995) showed that developmental rates in wheat were determined by mean temperature and not by day/ night amplitudes. Linear relationships between mean temperatures and rates of development during various growth phases were found for all the cultivars studied, but the temperature responses of the various cultivars differed significantly (Slafer and Rawson 1995). Timothy is an example of a species in which flowering is enhanced by diurnal temperature fluctuations as compared with constant temperatures (Junttila 1985).

When the photothermal requirements of a genotype for flowering are known from experimental studies, the data can be plotted on photothermographs for various localities. Predictions of flowering behaviour can then be made under corresponding climatic conditions. Roberts et al. (1993) have provided such examples for various cultivars of soyabeans, and Heide (1994) has used climate-phototherms to illustrate the climatic adaptation of primary induction of flowering in Bromus and Poa. Such exercises can be very useful for discussions on behaviour of plant species and genotypes under changing climatic conditions.

Adaptation to various germination temperatures has also been demonstrated in a number of species (Thompson 1973). Typically, species from high latitudes and high altitudes seem to have high optimum temperatures for germination, and germination is markedly restricted at lower temperatures (Junttila 1976a, 1976b). The specific requirements for germination temperature provide very clear examples of adaptation to temperature conditions. Such adaptations are necessary to synchronize the germination proc- ess with local growth conditions, and germination must be timed to periods that provide the highest probability of the young seedlings surviving and developing. These temperature requirements for germination are related to seed dormancy, and normally change drastically during the breaking of dormancy. Thus, in many cases the temperature requirement for seed germination has a highly plastic character, and is strongly modified by environmental conditions.

\section{Survival adaptation - frost resistance}

The ability to survive the winter is a basic requirement for perennial and winter annual plants growing at northern latitudes. Adaptations that promote winter survival include timing and rate of hardening, maximum level of hardiness, and timing and rate of dehardening. In woody plants, photoperiod is a signal for the initiation of hardening, but generally temperature conditions play a major role in the regulation of frost resistance. Although the maximum level of hardiness can be a limiting factor, the main problems are often linked to the correct synchronization of hardening and dehardening with the local temperature cycle. These processes have been studied extensively over the years, and many aspects of regulation and control of cold hardiness are now known. In herbaceous plants, the hardening-dehardening cycle is primarily controlled by temperature and is an example of physiological acclimation; resistance to low temperature improves when the temperature starts to fall, and the process is reversed when the temperature starts to rise (Levitt 1980). The effect of photoperiod on frost resistance in herbaceous plants is not as clear, although in some species, e.g. white clover, hardening is enhanced by short and dehardening by long photoperiod (Junttila et al. 1990b, Eagles 1994). Generally, plants of southern origin reach a lower level of maximum har- 


\section{AGRICULTURAL AND FOOD SCIENCE IN FINLAND}

\section{Junttila, O.: Plant adaptation to temperature and photoperiod}

diness than the corresponding northern genotypes, and there are also differences in the rates of hardening and dehardening. According to Eagles (1994), a UK cultivar of timothy dehardened in response to elevated temperature under short-day and long-day conditions, whereas a cultivar from northern Norway showed a marked daylength requirement, with dehardening being enhanced by a long photoperiod. A short photoperiod enhanced hardening of white clover genotypes from different latitudes, but the results did not indicate any significant adaptation to photoperiod (Junttila et al. 1990b).

The range of effective temperatures for hardening is so wide that a rise in temperature during the autumn and the spring of a few degrees from the present level would not necessarily be harmful for overwintering of cultivated or wild plants at our latitudes. However, if the climate change results in abrupt temperature variations during the hardening and dehardening periods, such conditions might have deleterious effects on genotypes in which resistance is sensitive to temperature. Studies on both perennial grass species and white clover indicate that populations from northern coastal areas, where snow and temperature conditions vary throughout the winter, often show a high degree of stability and strong winter resistance. At such locations, plants are, still today, exposed to such highly variable conditions.

\section{Genetic aspects of adaptation}

By definition, adaptation is a genetic process based on natural or human-imposed selection. Selection during domestication of our crop plants has resulted in genotypes with reduced seed dormancy, reduced dependence on photoperiod for flowering, and enhanced allocation of resources to the harvested parts of the plant (e.g. Evans 1993). Much of this development has happened without any deeper understanding of physiological or molecular nature of the processes in- volved. Several of the main crop species are now well characterized genetically, and present development in this field is very rapid. Most of the characteristics discussed above are considered to be quantitative. Photoperiodic responses in woody plants show a quantitative inheritance (Eriksson et al. 1978, Hummel et al. 1982, Junttila 1982, Junttila and Kaurin 1985). Similarly, frost resistance in F1 generation from a cross between a frost hardy and less a hardy genotype shows a clear intermediate inheritance (Røsnes et al., unpublished results). Quantitative characters, e.g. photoperiodic responses, may still be based on relatively few genes, as shown by $\mathrm{Pa}-$ terson et al. (1995) for sorghum, rice and maize. In these species, despite 65 million years of reproductive isolation, the quantitative loci for photoperiodic responses correspond closely. The ability of many cultivated cereals to flower in the long days of the temperate summer may largely be the result of mutations at a single ancestral locus (Paterson et al. 1995). In Chymomyza (a Drosophilidae) the critical photoperiod for diapause in $\mathrm{F} 1$ population is intermediate to that of parent populations and the photoperiodic response is controlled by few, perhaps no more than two loci (Riihimaa and Kimura 1989).

Frost resistance is a quantitative trait controlled by several genes (Levitt 1980), and intraspecific variation in frost resistance has been demonstrated in several cultivated species (see e.g. Hömmö 1994). In wheat, the chromosomes of the 5th homoeologous group and chromosomes 7A, 2B, 4B and 4D carry genes controlling frost resistance and winter hardiness. Chromosomes $5 \mathrm{~A}$ and $5 \mathrm{D}$, which have been implicated the most frequently, appear to carry major genes for frost resistance (Sutka et al. 1994). The locus for frost resistance (Frl) is located on the long arm of chromosome $5 \mathrm{~A}$ and seems to be completely linked to the locus Vrnl controlling the vernalization requirement. However, Vrn 1 and Fr1 genes are separable and could be targets for gene isolation and positional cloning. Further, there appears to be a close linking between Frl and the gene regulating abscisic acid (ABA) production in wheat (Galiba et al. 1994). 
Vol. 5 (1996): 251-260.

Larsen (1985) has provided an example of the effect of selection on frost resistance in Dactylis glomerata. Five per cent directional selection for high resistance significantly increased resistance within only three generations, particularly in a less-hardy cultivar (Unke). Selection in the opposite direction had only a minor effect.

In this regard, a puzzling phenomenon described for Norway spruce (Picea abies (L.) Karst.) and Scotch pine (Pinus sylvestris L.) should be mentioned. In repeated experiments, seeds produced from controlled crosses in a warm climate gave seedlings with an extended growth period and delayed frost hardening as compared with seedlings from similar crosses made in a cooler climate (Bjørnstad 1981, Johnsen 1989). The mechanisms for these effects are not known, but some evidence suggests a climatic effect (genetic or epigenetic) during pollination and fertilization (Johnsen et al., unpublished). Andersen (1971) has shown that the wintering capacity of a timothy cultivar can be significantly reduced after a few generations of seed production in a southern location.

\section{Physiological and molecular aspects of developmental adaptation}

Our knowledge of the physiological and molecular aspects of both the environmental and internal regulation of plant growth and development is rapidly expanding, and the progress made in different fields is frequently reviewed in proceedings and periodicals. Improved methods for molecular mapping, identification of genes, studies on mechanisms of gene regulation, and utilization of gene transfer techniques provide us with unique possibilities to manufacture plants with designed properties, including responses to climatic factors, if so desired. The following three examples are particularly relevant to the developmental processes discussed above.
Known to be of great importance for metabolism in plant cells, the lipid composition of plant membranes is affected by temperature, and changes in the fatty acid composition of membrane lipids are related to a plant's ability to grow at low temperatures. The role of membrane lipids in temperature related growth processes has been well demonstrated with mutants and transgenic plants of Arabidopsis. Plants deficient in desaturase activity, and therefore lacking polyunsaturated fatty acids, are not able to grow at low temperatures. Decreased desaturase activity thus turns a cold-tolerant plant into a coldsensitive plant (Miquel et al. 1993). The importance of trienoic fatty acid composition in conditioning cold tolerance has also been demonstrated in transgenic tobacco (Kodama et al. 1994). Clearly, modification of membrane lipids by gene technology provides new possibilities for changing plant responses to temperature. The future of this field was discussed at length in a recent review by Gibson et al. (1994).

Phytochrome is the primary receptor involved in light perception for photoperiodic responses, shade avoidance, proximity perception, seed germination, etc. Higher plants have at least five different phytochromes. The genes for several of these phytochromes have already been cloned and the effects of these genes have been studied in transgenic plants (Smith 1994). Both transgenic plants and phytochrome mutants show markedly changed responses to light quality (spectral composition), irradiance and photoperiod, and phytochrome genes can, moreover, strongly modify plant growth and development. Smith (1992) has discussed the prospects for improving cultivated plants by genetic modifications of the phytochrome system.

There is increasing evidence that plant hormones play an important role in mediating climatic signals into growth responses. Plant hormones are also strongly involved in various acclimation processes and the control of plasticity of plant growth (see also Trewavas 1986). The identification and characterization of various hormone mutants in different plant species (Reid and Howell 1995) have provided convincing 
Junttila, O.: Plant adaptation to temperature and photoperiod

evidence that plant hormones are important components of the adaptation mechanisms of developmental processes. In particular, ABA and gibberellins (GA) are involved in the climatic regulation of plant growth. ABA is crucial for the regulation of water balance in plants (Zeevaart and Creelman 1988). Plants unable to synthesize ABA are not cabable of regulating stomata closure, and are thus highly vulnerable to drought stress. ABA can also function as a drought related signal from the roots to the top of the plants (Davies and Zhang 1991). The role of ABA in regulating freezing stress tolerance has also been documented in a number of studies (Chen and Gusta 1983, Reaney et al. 1989).

GAs are involved in the regulation of seed germination, vegetative growth, flowering and seed and fruit growth (Graebe 1987). Several studies suggest that biosynthesis of GAs in plants can be affected by light and temperature (for references, see Graebe 1987, Takahashi et al. 1991). Thus, both photoperiodic responses and certain temperature responses, e.g. vernalization and elongation growth, could be linked to environmental regulation of endogenous GAs in plants. Genes coding for some of the enzymes in biosynthetic pathways for GAs have recently been cloned (Lange et al. 1994), providing new opportunities for more precise analyses of the functions and roles of GAs in regulating plant growth and development.

In conclusion, higher plants have evolved effective mechanisms to acclimate and to adapt to temperature and photoperiod. The developmental processes in plants are especially adaptable and plastic, and have been subjected to both natural and human imposed selection. Plant species and ecotypes adapted to various environmental conditions have developed through evolution. Furthermore, plant breeding has brought about a wide selection of cultivars for various purposes and environments. The capacity for plastic behaviour found in many plants enhances their potential to tackle changing environmental conditions. Understanding the genetic and physiological control of the mechanisms behind the responses of plants to climatic conditions is now rapidly expanding.

Despite the complexity of the mechanisms in the climatic regulation of developmental processes in plants, the examples discussed above suggest that molecular biology will eventually be able to provide effective means to tailor plants for specific environmental conditions.

Acknowledgements. Thanks are due to Professor Ronald Robberecht, University of Idaho, Moscow, Idaho, U.S.A., for valuable comments on the manuscript. The Norwegian Research Council is acknowledged for financial support.

\section{References}

Andersen. I. L. 1971. Overvintringsforsøk med ulike grasarter. (Investigations on the wintering of some forage grasses.) Forskning og forsøk i landbruket 22: 121-134. Bjornstad, Á. 1981. Photoperiodical after-effects of parent plant environment in Norway spruce (Picea abies (L.) Karst) seedlings. Meddelande fra Norsk Institutt for Skogforskning 36: 1-30.

Chen, T. H. H. \& Gusta, L. V. 1983. Abscisic acid-induced freezing resistance in cultured plant cells. Plant Physiology 73: 71-75.

Cooper, J. P. 1964. Climatic variation in forage grasses. I. Leaf development in climatic races of Lolium and Dactylis. Journal of Applied Ecology 1: 45-61.

Davies, W. J. \& Zhang, J. 1991. Root signals and the regulation of growth and development of plants in drying soils. Annual Review of Plant Physiology and Plant Molecular Biology 42: 55-76.

Dormling, I., Gustafsson, Å. \& Wettstein, D. von 1968. The experimental control of the life cycle in Picea abies (L.) Karst. I. Some basic experiments on the vegetative cycle. Silvae Genetica 17: 44-64.

Eagles, C. F. 1967. The effect of temperature on vegetative growth in climatic races of Dactylis glomerata in controlled environments. Annals of Botany 31: 31-39.

- 1994. Temperature, photoperiod and dehardening of forage grasses and legumes. In: Dörffling, K. et al. (eds.). Crop Adaptation to Cool Climates, Proceedings COST 814 workshop, October 12-14, 1994, ECSP-EEC-EAEC, Brussels, Belgium. p. 75-82.

Eriksson, G., Ekberg, I., Dormling, I. \& Matern, B. 1978. 


\section{AGRICULTURAL AND FOOD SCIENCE IN FINLAND}

Vol. 5 (1996): 251-260.

Inheritance of bud-set and bud-flushing in Picea abies (L.) Karst. Theoretical and Applied Genetics 52: 3-19.

Evans, L. T. 1993. Crop evolution, adaptation and yield. Cambridge University Press, Cambridge. 500 p.

Galiba, G., Sutka, J., Snape, J. W., Tuberosa, R., Quarrie, S. A., Sarkadi, L. \& Veisz, O. 1994. The association of frost resistance gene $\mathrm{Fr} 1$ with stress-induced osmolyte and abscisic acid accumulation in wheat. In: Dörffling, K. et al. (eds.). Crop Adaptation to Cool Climates, Proceedings COST 814 workshop, October 12-14, 1994, ECSP-EEC-EAEC, Brussels, Belgium. p. 389-401.

Gibson, S., Falcone, D. L., Browse, J. \& Somerville, C. 1994. Use of transgenic plants and mutants to study the regulation and function of lipid composition. Plant, Cell and Environment 17: 627-637.

Graebe, J. E. 1987. Gibberellin biosynthesis and control. Annual Review of Plant Physiology 38: 419-465.

Grime, J. P., Crick, J. C. \& Rincon, J. E. 1986. The ecological significance of plasticity. In: Jennings, D. H. and Trewavas, A. J. (eds). Plasticity in Plants, SEB Symposia 40, The Society for Experimental Biology, Cambridge, U.K. p. 5-30.

Hábjorg, A. 1978. Photoperiodic ecotypes in Scandinavian trees and shrubs. Meldinger fra Norges landbrukshøgskole 57(33): 1-20.

Hay, R. K. M. 1990. The influence of photoperiod on the dry-matter production of grasses and cereals. Transley Review No. 26. New Phytologist 116: 233-254.

- \& Heide, O. M. 1983. Specific photoperiodic stimulation of dry matter production in a high-latitude cultivar of Poa pratensis. Physiologia Plantarum 83: 135-142.

Heide, O. M. 1974 . Growth and dormancy in Norway spruce ecotypes (Picea abies). I. Interaction of photoperiod and temperature. Physiologia Plantarum 30: 1-12. - 1977. Photoperiod and temperature interactions in growth and flowering of strawberry. Physiologia Plantarum 40: 21-26.

- 1982. Effects of photoperiod and temperature on growth and flowering in Norwegian and British timothy cultivars (Phleum pratense L.). Acta Agriculturae Scandinavica 32: 241-252.

- 1986. Long day control of flowering in Poa nemoralis in controlled and natural environments. New Phytologist 104: 225-232.

-1994 . Control of flowering and reproduction in temperate grasses. New Phytologist 128:347-362.

Hummel, R. L., Ascher, P. D. \& Pellett, H. M. 1982. Inheritance of photoperiodically induced cold acclimation response in Cornus serica L., Red-osier dogwood. Theoretical and Applied Genetics 62: 385-394

Hömmö, L. M. 1994. Resistance of winter cereals to various winter stress factors - inter- and intraspecific variation and the role of cold acclimation. Agricultural Science in Finland 3, Supplement 1. Dissertation.

Jones, D. A. \& Wilkins, D. A. 1971. Variation and adaptation in plant species. Heinemann Educational Books Ltd, London. $184 \mathrm{p}$.

Johnsen, Ø. 1989. Phenotypic changes in progenies of northern clones of Picea abies (L.) Karst. grown in a southern seed orchard. I. Frost hardiness in a phytotron experiment. Scandinavian Journal for Forest Research 4: $317-330$.
Junttila, O. 1976a. Dormancy in caryopsis of various Dactylis glomerata L. populations. Seed Science and Technology 5: 463-471.

- 1976b. Seed germination and viability of five Salix species. Astarte 9: 19-24.

- 1980. Effect of photoperiod and temperature on apical growth cessation in two ecotypes of Salix and Betula. Physiologia Plantarum 48: 347-352.

- 1982. Cessation of apical growth in latitudinal ecotypes and ecotype crosses of Salix pentandra L. Journal of Experimental Botany 33: 1021-1029.

- 1985. Experimental control of flowering and vivipary in timothy (Phleum pratense). Physiologia Plantarum 63: 35-42.

- \& Kaurin, Å. 1985. Climatic control of apical growth cessation in latitudinal ecotypes of Salix pentandra L. In: Kaurin, A. et al. (eds.). Plant Production in the North. Norwegian University Press, Oslo. p. 83-91.

- \& Schjelderup, I. 1984. Seed production and vivipary in timothy. Proceedings of the European Grassland Federation 10th Meeting, Ass, Norway, p. 51-55.

-, Svenning, M. M. \& Solheim, B. 1990a. Effects of temperature and photoperiod on vegetative growth of white clover (Trifolium repens) ecotypes. Physiologia Plantarum 79: 427-434.

-, Svenning, M. M. \& Solheim, B. 1990b. Effects of temperature and photoperiod on frost resistance of white clover (Trifolium repens) ecotypes. Physiologia Plantarum 79: 435-438.

Kodama, H. , Hamada, T., Horiguchi, G., Nishimura, M. \& Iba, K. 1994. Genetic enhancement of cold tolerance by expression of a gene for chloroplast omega-3 fatty acid desaturase in transgenic tobacco. Plant Physiology 105: 601-605.

Koski, V. 1985. Adaptation of trees to the variation in the length of the growing season. In: Kaurin, $\AA$. et al. (eds.). Plant Production in the North. Norwegian University Press, Oslo. p. 267-276.

Lange, T., Hedden, P. \& Graebe, J. E. 1994. Expression cloning of a gibberellin 20-oxidase, a multifunctional enzyme involved in gibberellin biosynthesis. Proceedings of the National Academy of Sciences USA 91: 85528556.

Lankinen, P. 1986. Geographical variation in circadian eclosion rhythm and photoperiodic diapause in Drosophila littoralis. Journal of Comparative Physiology A 159: 123142.

Larsen, A. 1985. Response to selection for freezing tolerance and associated effects on vegetative growth in Dactylis glomerata. In: Kaurin, A. et al. (eds.). Plant Production in the North. Norwegian University Press, Oslo. p. $134-140$.

Levitt, J. 1980. Responses of plants to environmental stresses: Chilling, freezing and high temperature stresses. 2nd ed., Vol. 1. Academic Press, New York. 497 p. Miquel, M., James, D. Jr., Dooner, H. \& Browse, J. 1993. Arabidopsis requires polyunsaturated lipids for lowtemperature survival. Proceedings of the National Academy of Sciences, USA 90: 6208-6212.

Paterson, A. H., Lin, Y-R., Li, Z., Schertz, K. F., Doebley, J. F., Pinson, S. R. M., Liu, S-C., Stansel, J. W. \& Irvine, J. E. 1995. Convergent domestication of cereal 


\title{
AGRICULTURAL AND FOOD SCIENCE IN FINLAND
}

Junttila, O.: Plant adaptation to temperature and photoperiod

crops by independent mutations at corresponding genetic loci. Science 269: 1714-1718.

Reaney, M. J. T., Ishikawa, M., Robertson, A. J. \& Gusta, L. V. 1989. The induction of cold acclimation: the role of abscisic acid. In: Li, P. H. (ed.). Low temperature stress physiology in crops. CRC Press, Boca Raton, FL. p. 3-25.

Reid, J. B. \& Howell, S. H. 1995. Hormone mutants and plant development. In: Davies, P. J. (ed.). Plant hormones, physiology, biochemistry and molecular biology. Kluwer Academic Publsiher, Dordrecht, Boston, London. p. 448485.

Riihimaa, A. J. \& Kimura, M. T. 1989. Genetics of the photoperiodic larval diapause in Chymomyza costata (Diptera: Drosophilidae) Hereditas 110: 193-200.

Roberts, E., Summerfield, R.J., Ellis, R. \& Qi, A. 1993. Adaptation of flowering in crops to climate. Outlook on Agriculture 22: 105-110.

Slafer, G. A. \& Rawson, H. M. 1995. Base and optimum temperatures vary with genotype and stage of development in wheat. Plant, Cell and Environment 18: 671-679. Smith. H. 1992. The ecological functions of the phytochrome family, clues to a transgenic programme of crop improvement. Photochemistry and Photobiology 56: 815822.

- 1994. Physiological and ecological function within the phytochrome family. Annual Review of Plant Physiology and Plant Molecular Biology 46: 289-316.

Summerfield, R. J., Roberts, E. H., Ellis, R. H. \& Lawn, R. J. 1991. Towards the reliable prediction of time to flowering in six annual crops. I. The development of simple models for fluctuating field environments. Experimental Agriculture 27: 11-31.
Sutka, J., Galiba, G., Quarrie, S. A., Veisz, O. \& Snape, J. W. 1994. Cytogenetic studies on frost resistance in wheat (Triticum aestivum L.). In: Dörffling, K. et al. (eds.). Crop Adaptation to Cool Climates, Proceedings COST 814 workshop, October 12-14, 1994, ECSP-EEC-EAEC, Brussels, Belgium. p. 377-387.

Takahashi, N., Phinney, B. O. \& MacMillan, J. 1991. Gibberellins. Springer Verlag, New York. p. 426.

Tashiro, T. \& Wardlaw, I. F. 1989. A comparison of the effect of high temperature on grain development in wheat and rice. Annals of Botany 64: 59-65.

Thompson, P. A. 1973. Geographic adaptation of seeds. In: Heydecker, W. (ed). Seed Ecology, Butterworths, London. p. 31-58.

Trewavas, A. J. 1986. Resource allocation under poor growth conditions. A major role for growth substances in developmental plasticity. In: Jennings, D. H. \& Trewavas, A. J. (eds). Plasticity in Plants, SEB Symposia 40, The Society for Experimental Biology, Cambridge, U.K. p. 31-76.

Turesson, G. 1922. The genotypic response of the plant species to the habitat. Hereditas 3: 211-350.

Vaartaja, O. 1954. Photoperiodic ecotypes of trees. Canadian Journal of Botany 32: 392-399.

Wareing, P. F. 1979. Temperature responses and yield in temperate crops. In: Scott, T. K. (ed). Plant regulation and world agriculture. Plenum Press, New York and London. p. 129-139.

Went, F. W. 1957. The experimental control of plant growth. Ronald, New York. 343 p.

Zeevaart, J. A. D. \& Creelman, R. A. 1988. Metabolism and physiology of abscisic acid. Annual Review of Plant Physiology and Plant Molecular Biology 39: 439-473.

\section{SELOSTUS}

\section{Kasvien sopeutuminen lämpötilaan ja päivän pituuteen}

\author{
Olavi Junttila \\ University of Troms, , Norja
}

Kasvien kyky kasvaa, lisääntyä ja talvehtia vaihtuvissa ilmastollisissa olosuhteissa riippuu suurelta osalta niiden kyvystä sopeutua ympäristöön geneettisesti (adaptaatio) ja fenotyyppisesti (akklimaatio). Eläimiin verrattuna kasvien sopeutumiskyky on varsin hyvä etenkin sellaisten ominaisuuksien suhteen, jotka ovat merkittäviä kasvulle, kehittymiselle ja kylmänkestävyydelle. Artikkelissa käsitellään kasvien sopeutumista lämpötilaan ja päivän pituuteen. Tällai- nen sopeutuminen on selvintä kasvien kehitystä ja kehitysrytmiä säätelevien mekanismien kohdalla. Yksivuotiset kasvit sopeutuvat ennen kaikkea kukinnan ja lisääntymisen avulla. Monivuotiset kasvit sopeutuvat lisäksi säätelemällä vuotuista kasvu-leporytmiä. Artikkelissa esitetään esimerkkejä sekä yksiettä monivuotisten kasvien sopeutumisesta, ja käsitellään lyhyesti sopeutumisen fysiologista ja geneettistä taustaa. 